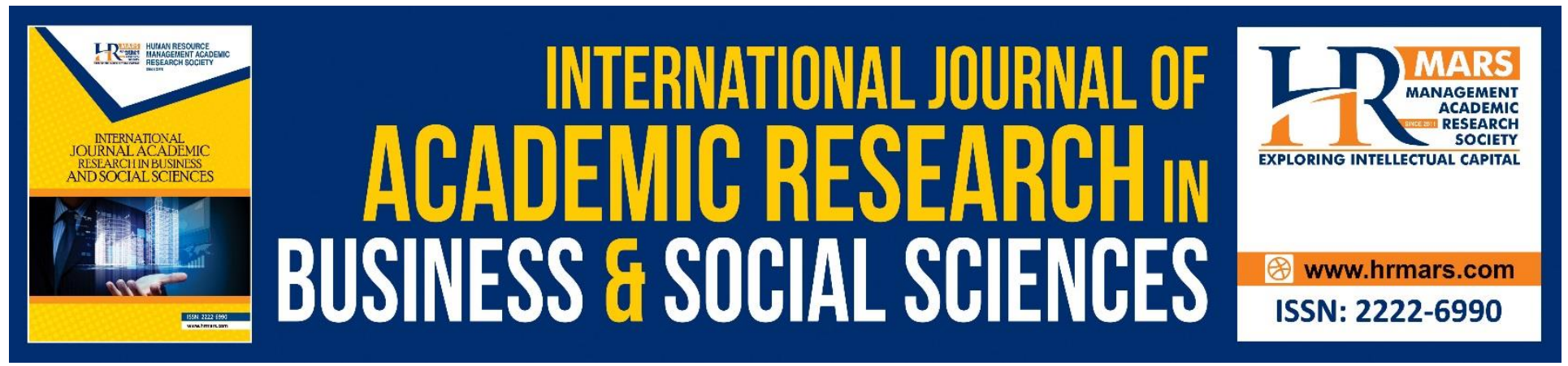

\title{
High-Order Thinking Skill (HOTS) of the Students in Aspect of Understanding Modern Poetry and Prose of Malay Language
}

Abdul Rasid Jamian, Wan Nazira Wan Jaafar, Shamsudin Othman, Azhar Md. Sabil

To Link this Article: http://dx.doi.org/10.6007/IJARBSS/v8-i12/5152

DOI: $10.6007 /$ IJARBSS/v8-i12/5152

Received: 03 Nov 2018, Revised: 19 Dec 2018, Accepted: 28 Dec 2018

Published Online: 31 Dec 2018

In-Text Citation: (Jamian, Jaafar, Othman, \& Sabil, 2018)

To Cite this Article: Jamian, A. R., Jaafar, W. N. W., Othman, S., \& Sabil, A. M. (2018). High-Order Thinking Skill (HOTS) of the Students in Aspect of Understanding Modern Poetry and Prose of Malay Language. International Journal of Academic Research in Business and Social Sciences, 8(12), 1043-1058.

Copyright: (C) 2018 The Author(s)

Published by Human Resource Management Academic Research Society (www.hrmars.com)

This article is published under the Creative Commons Attribution (CC BY 4.0) license. Anyone may reproduce, distribute, translate and create derivative works of this article (for both commercial and non-commercial purposes), subject to full attribution to the original publication and authors. The full terms of this license may be seen

at: http://creativecommons.org/licences/by/4.0/legalcode

Vol. 8, No. 12, 2018, Pg. 1043 - 1058

http://hrmars.com/index.php/pages/detail/IJARBSS

JOURNAL HOMEPAGE

Full Terms \& Conditions of access and use can be found at http://hrmars.com/index.php/pages/detail/publication-ethics 


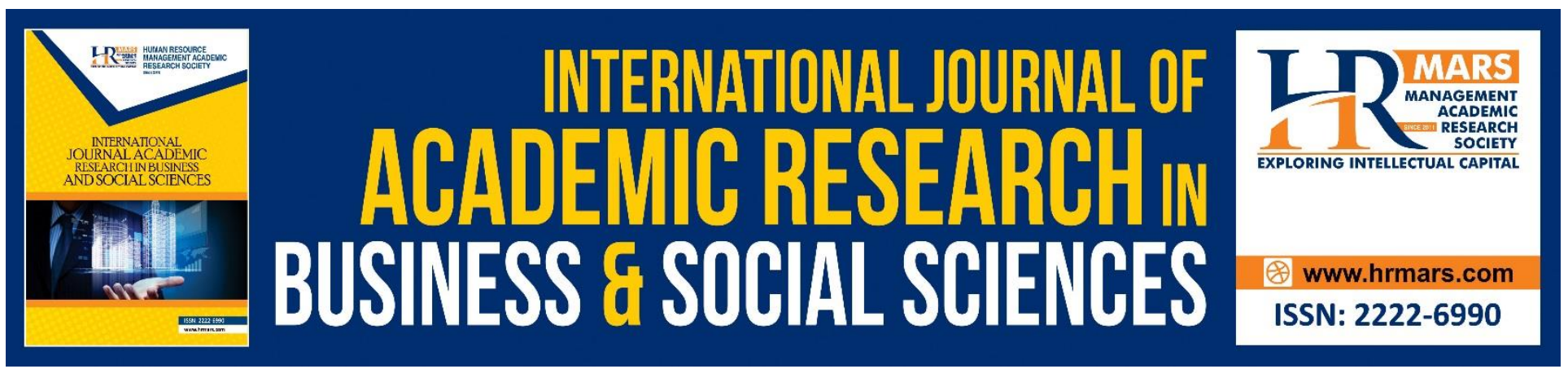

\title{
High-Order Thinking Skill (HOTS) of the Students in Aspect of Understanding Modern Poetry and Prose of Malay Language
}

\author{
Abdul Rasid Jamian, Wan Nazira Wan Jaafar, Shamsudin Othman, \\ Azhar Md. Sabil \\ Faculty of Educational Studies, Universiti Putra Malaysia, 43400 UPM Serdang, Selangor Darul \\ Ehsan, Malaysia
}

\begin{abstract}
This study aimed to evaluate high order thinking skill (HOTS) proficiency of students in the understanding of poetry and prose of modern Malay. The samples were carried out in this study were 210 students using quantitative methods as the study design. The findings showed that HOTS for understanding poetry is moderate (mean=2.35, $\mathrm{SD}=1: 07$ ), while the understanding of modern prose is at a high level (mean=2.67, SD=0.98). There are no significant differences between gender in the understanding of modern poetry, but there are significant differences between female students (mean=2.83, SD=0.91) and boys (mean=2.47, SD=1.03) in the understanding of modern prose. Significant differences between the level of HOTS in terms of understanding the poem ( $m e a n=3.38$, $\mathrm{SD}=0.64$ ), prose (mean $=3.13, \mathrm{SD}=0.54$ ) as well as modern poetry and prose (mean=3.25, $\mathrm{SD}=0.49$ ) among students of high level, medium and low can also be seen. In conclusion, the HOTS should be mastered by students not only academically but also non-academically and the practice of appling HOTS in them through appropriate teaching methods can improve their performance in their studies. Keywords: Higher Level Thinking Skills; Poetry Understanding; Modern Prose; Literature Component in Malay Language; Students
\end{abstract}

\section{Introduction}

The National Education Philosophy (NEP) aims to produce balanced and harmonious human being from all aspects of life including physical, emotional, spiritual, intellectual, and social (JERIS). Similarly, the teaching of Bahasa Melayu that should be according to the FPK. This means that nowadays education is producing highly educated and competent citizens. In line with the Ministry of Education (MOE) policy through the Malaysian Education Development Plan (PPPM) in 2013-2025 has highlighted the High-order Thinking Skills (HOTS) in which the content is applied into all primary school subjects as well as high school. 
The Ministry of Education Malaysia (MOE) has reviewed and examined in detail that the Lower Secondary Assessment (PMR) has been replaced by the Form Three Assessment (PT3) in 2014. The KBAT question in 2014 became a pioneer for Grade 4 pupils and Form 2 students. As been announced in 2016, $40 \%$ of the questions that will be asked are related to HOTS. It means that the focus of the questions in this assessment is more on high-level thinking. The previous PMR question requires students to answer in the form of multiple choices, but as PT3 which began last year, students are required to think before answering and questions are more subjective as they need to write and build correct sentences to get excellence score.

According to the Malaysian Examinations Board (LPM) (2013), states that the ratio of questions will be increased to test HOTS in School-Based Assessment (PBS) and public examinations systematically over the next three years. The HOTS questions are based on the revision of Bloom taxonomy that test the skills of applying, analyzing, evaluating, and generating ideas. This assessment will also be enhanced further by inculcating creative skills and problem solving. HOTS items involve broader scopes, diverse methods and stimuli as well as challenging but can be assessed because the basic knowledge either learned, through experience, reading or else is used as an essential requirement to stimulate students' higher-order thinking.

Higher-order thinking skills are now taken place in the education realm as it has been employed into the Malaysia Education Development Plan (PPPM). According to PPPM, there are 6 main features that every student needs to be able to compete globally which are: knowledge; national identity; leadership skills; bilingual skills; thinking skills; and ethics and spirituality.

\section{Problem Statement}

Programme International Student Assessment (PISA) that has been organized in our country in 2009 has recorded a very low achievement. This situation is really grieving because our country's education system has generally spent a lot to finance such programme. The investigation by the Ministry of Education Malaysia found out that the PISA questions merely focus on problem solving. Therefore, students need to think at high order to answer the question particularly in term of analysis, evaluation and design from the Bloom Taxonomy revised edition.

This is clearly shows that our national education system is still inadequate in providing skilledstudents in term of high-order thinking skill. They also do not know how to connect the various knowledge within the lesson inside the classroom. The thoughts that they highlighted are also fairly subtle even though their level of achievement is moderate and high. Students are also said to be lazy to think and always wait for answers from teachers even sometimes it is only a lower level question such as knowing, understanding or applying. 
Generally, teaching and learning process that is based on HOTS will be the main agenda in schools. However, our national education system has not yet introduced a specific subject on thinking skill inside the classroom. Specifically, Malay language subject requires a high level of thinking particularly on the subject of this study, the comprehensive question of poetry and prose. As 2014 was the first year of Form Three students entitled to the Form Three Assessment (PT3), thus assessing the HOTS questions in aspect of poetry and prose understanding making it suitable for researchers to do a research and study on KBAT among the students.

Hence, the study conducted by Zamri Mahamod and Nor Razah Lim (2011) aimed to know the methods and the frequency of oral questionnaires used by Malay language teachers in teaching and learning process. The finding of their study shows that the teachers are frequently asking questions in the classroom. However, the method of questioning used does not involve high-order questioning, instead, the teachers merely focus on low and medium-order questioning. In addition, the questions used by these Malay teachers are not involved external aspects as expected by the Ministry of Education Malaysia (KPM) like PISA which is focused on the outside world and not just individual aspects and society. The implication of this, the students only think on the matter that in front of them because the teachers failed to infuse high-order questioning in the study.

Based on Chew Fong Peng (2014), who have reviewed the implementation of critical and creative thinking skills (KBKK) in the teaching and learning of literacy components (KOMSAS). The finding showed that most respondents of teachers and students agreed with the implementation of KBKK in teaching and learning KOMKAS. This is because the teacher always encourages students to participate in teaching and learning that involve KBKK activities. However, for the effectiveness of KBKK practice, he found that pupils are uncertain and still confused with the activities carried out by the teachers in the classroom whether they have implemented KBKK practice or not. According to him, teachers are not really participated in KBKK activities such as attending courses related to KBKK. Therefore, the teachers are not being able to do any activities that based on the KBKK in the classroom effectively

\section{Significant of Study}

In today's era, students need to be trained to think so they are ready to face the challenging world. Thinking activities can have a good impact to enhance their potential in learning. HOTS also gives students the opportunity to present their thoughts in solving problems or issues discussed.

HOTS that has been implemented also helps to produce highly educated students in all fields. This research finding on HOTS is expected to be a source of reference to the Chairman of the Malay Language Committee and also educators of whole Malaysia. It is also hoped that this study will guide the respected bodies in preparing, formulating, and generating items based on the appropriate HOTS in KOMSAS Malay Language comprehension. In addition, it is hoped the teachers or educators acknowledge that KBAT needs to be taught systematically on comprehension aspects of modern and traditional poetry and prose of Malay language, so that the students able to think at higher level on any issue and able resolve it rationally inside or outside of school later. 
INTERNATIONAL JOURNAL OF ACADEMIC RESEARCH IN BUSINESS AND SOCIAL SCIENCES

Vol. 8, No. 12, Dec, 2018, E-ISSN: 2222-6990 C 2018 HRMARS

\section{Objective of Study}

The general objective of this study is to analyze the ability of students to use HOTS to answer poetry and prose comprehension questions in KOMSAS. In particular, this study was aimed to achieve the

following objectives:

1. Identifying HOTS level of form three students in aspect of understanding modern poetry and prose

2. Identifying if there is a difference of HOTS between male and female students in aspect of understanding modern poetry and prose

3. Identifying if there is a difference of HOTS achievement level in aspect of understanding modern poetry and prose between high, medium and low level students.

\section{Research Question}

Research questions are also being developed to get more efficient and effective results. The research questions are as follows:

1. What is the HOTS level of form three students on aspect of understanding poetry and modern prose?

2. Is there a difference of HOTS between male and female students in understanding poetry and modern prose?

3. Is there a difference of HOTS achievement level in understanding poetry and modern prose between high, medium and low level students?

\section{Research Methodology}

The research design of this study is descriptive. The study aims to review HOTS of Form 3 students in the aspect of poetry comprehension and modern prose of KOMSAS Bahasa Melayu in a secondary school in Gombak, Selangor. The researcher wanted to know the mastery facet of HOTS of form three students on comprehension aspect of modern Malay poetry and prose.

\section{Population and Research Sample}

The chosen school in this study was SMK Darul Ehsan. Total number of form three students in this school is 443. This data was obtained through teacher's data of SMK Darul Ehsan. The school which is located in Selayang Baru is a school in the suburb of Selayang. The total sample for this study was 210 as adhered to Krejcie \& Morgan formula (1970), which was based on the population of 443 Form Three students.

\section{Research Instrument}

The research instrument that has been used was a question test of Form Three Assessment (PT3). According to Noraini Idris (2010), most researchers were using either an instrument designed by the publisher, designed by the researcher himself or standard instrument. Thus, the researcher has 
INTERNATIONAL JOURNAL OF ACADEMIC RESEARCH IN BUSINESS AND SOCIAL SCIENCES

Vol. 8, No. 12, Dec, 2018, E-ISSN: 2222-6990 C 2018 HRMARS

constructed question items represented by one division only. The instrument of this study was aimed to obtain information of 7 research questions which consist of 6 questions including poetry and modern prose questions that used Bloom Taxonomy revision of cognitive level which is related to KBAT. The study was conducted by using two types of comprehension quotes as identical to the real PT3 question:

Question 1: Comprehension passage of Modern poetry followed by three questions of HOTS level Question 2: Comprehension passage of modern prose that also followed by three questions of HOTS level

Hence, these questions are appropriate to see the level of high-order thinking skill of the Form 3 students in this study. (Refer Table 1 and 2)

Table 1: Modern Poetry Research Question HOTS -Based According to Bloom Taxonomy

\begin{tabular}{llrl}
\hline No & Modern Poetry Questions & Adverb/verb process & Level/contruct \\
\hline 1 & $\begin{array}{l}\text { Can you explain the consequences } \\
\text { of taking drug on an individual? }\end{array}$ & $\begin{array}{r}\text { Characterizing, } \\
\text { Problem solving, } \\
\text { Conclusion making }\end{array}$ & Analysing \\
2 & $\begin{array}{l}\text { Why are those who involved in } \\
\text { drug addiction are wasting human } \\
\text { resource of the country? }\end{array}$ & Making assumptions, designing/ \\
Thinking, generating idea & Characterizing & \\
3 & $\begin{array}{l}\text { In your opinion, what is the best } \\
\text { solution for combating drug } \\
\text { abuse? }\end{array}$ & $\begin{array}{r}\text { Making decision, Evaluating } \\
\text { Rationalizing, } \\
\text { Detecting }\end{array}$ & \\
\hline
\end{tabular}


INTERNATIONAL JOURNAL OF ACADEMIC RESEARCH IN BUSINESS AND SOCIAL SCIENCES Vol. 8, No. 12, Dec, 2018, E-ISSN: 2222-6990 @ 2018 HRMARS

Table 2: Modern Prose Research Question HOTS -based According to Bloom Taxonomy

\begin{tabular}{llll}
\hline No & Modern prose question & Adverb/Verb process & Level/contruct \\
\hline 1 & $\begin{array}{l}\text { Based on the above passage, what } \\
\text { is your assumption if a mother is } \\
\text { being strict on her kid since small? }\end{array}$ & Making conclusion, \\
2 & $\begin{array}{l}\text { In your opinion, why educterize } \\
\text { important for a teenager as } \\
\text { emphasized by the author? }\end{array}$ & Aninking, \\
3 & $\begin{array}{l}\text { After reading this story passage, rationalizing, } \\
\text { what do you do to change the kid's } \\
\text { attitude if you are one of kid's Supporting } \\
\text { family member? }\end{array}$ & Evaluating \\
\end{tabular}

The scoring scale that is used to examine the test answers of the respondents is by referring to the scheme from the Malaysian Examinations Board (2013), in HOTS Assessment. The scoring rule has been changed by the researcher to match the test questions with the original score of PT3. According to the Malaysian Examinations Board (2013), the scoring or scoring method consists of checklists and mark scales. In the context of this study, rubric would be provided by the researcher acting as scoring guide to assess student achievement based on a wide range of criteria.

\section{Data Collection Procedures}

Researchers should follow procedures in collecting research data. In running the test, the students should answer the comprehension questions within 40 minutes; poetry comprehension question for 20 minutes while modern prose is also for 20 minutes. The short time allocated is compatible with PT3 in which within 2 hours the students need to solve various aspects such as grammar, komsas including (modern or traditional poetry, modern or traditional prose as well as novel questions), reviews and essays. Then, the instruments are taken for scoring.

\section{Data analysis}

In analyzing data instrument of comprehension question test (modern poetry and prose) requires descriptive and inferential statistical analysis such as t-test and one-way ANOVA. Table 3, shows the data analysis conducted by the researcher. 
INTERNATIONAL JOURNAL OF ACADEMIC RESEARCH IN BUSINESS AND SOCIAL SCIENCES

Vol. 8, No. 12, Dec, 2018, E-ISSN: 2222-6990 C 2018 HRMARS

Table 3: Analyzing Data Methods

\begin{tabular}{|c|c|}
\hline Objective & Data Analysis Method \\
\hline $\begin{array}{l}\text { 1. Identifying KBAT level of form three students in } \\
\text { aspect of understanding modern poetry and prose }\end{array}$ & Descriptive \\
\hline $\begin{array}{l}\text { 2. Identifying if there is a difference of KBAT between } \\
\text { male and female students in aspect of } \\
\text { understanding modern poetry and prose }\end{array}$ & T-test \\
\hline $\begin{array}{l}\text { 3. Identifying if there is a difference of KBAT } \\
\text { achievement level in aspect of understanding } \\
\text { modern poetry and prose between high, medium } \\
\text { and low level students. }\end{array}$ & Anova \\
\hline
\end{tabular}

\section{Research Finding}

\section{Respondent Demographics}

Respondents of the study consist of 210 Form 3 students at a secondary school in Gombak district. The findings showed that 116 (55.2\%) were female students while 94 (44.8\%) were male students.

For respondents' distribution by class based on the students' ability level, the respondents were divided into three categories: Upper, Average and Lower. 78 respondents (37.1\%) from average class, 69 (32.9\%) lower class, and 63 (30\%) upper class as Table 4 below.

Table 4: Number and Percentage of Respondents by Level

\begin{tabular}{ccc}
\hline Class Level & Frequency (f) & Percentage (\%) \\
\hline Upper & 63 & 30.0 \\
Average & 78 & 37.1 \\
Lower & 69 & 32.9 \\
\hline Total & $\mathbf{2 1 0}$ & $\mathbf{1 0 0 . 0}$ \\
\hline
\end{tabular}

Identifying HOTS level of form three students in aspect of understanding modern poetry and prose In relation to the HOTS level of form 3 students in aspect of understanding modern poetry and prose classified as low, medium and high. Refer to table 5 below. 
INTERNATIONAL JOURNAL OF ACADEMIC RESEARCH IN BUSINESS AND SOCIAL SCIENCES

Vol. 8, No. 12, Dec, 2018, E-ISSN: 2222-6990 @ 2018 HRMARS

Table 5: Levels of HOTS Form 3 pupils in Aspect of Understanding Modern Poetry and Prose

\begin{tabular}{|l|l|l|l|l|}
\hline HOTS (Modern Poetry) & Frequency(f) & $\begin{array}{l}\text { Percentage } \\
(\mathbf{\%})\end{array}$ & Mean & SD \\
\hline Low & 61 & 29 & & \\
\hline Medium & 84 & 40 & & \\
\hline High & 65 & 31 & & \\
\hline Total & $\mathbf{2 1 0}$ & $\mathbf{1 0 0 . 0}$ & $\mathbf{2 . 3 5}$ & $\mathbf{0 . 8 3}$ \\
\hline
\end{tabular}

The findings showed that the HOTS level in aspect of understanding modern poetry and prose is 84 respondents (40\%) have medium HOTS level, 65 (31\%) have high HOTS level, and 61 (29\%) have level low HOTS. Overall, their HOTS level is at a moderate level with values (mean $=2.35 ; \mathrm{SD}=0.83$ ) as in the Table 6 below:

Table 6: Data in Aspect of Understanding Modern Poetry

\begin{tabular}{|l|l|l|l|}
\hline Item & Statement & Mean & SD \\
\hline 1 & $\begin{array}{l}\text { Can you explain the consequences of taking drug on an } \\
\text { individual? }\end{array}$ & 2.93 & 1.07 \\
\hline 2 & $\begin{array}{l}\text { Why are those who involved in drug addiction are } \\
\text { wasting human resource of the country? }\end{array}$ & 1.92 & 1.01 \\
\hline 3 & $\begin{array}{l}\text { In your opinion, what is the best solution for combating } \\
\text { drug abuse? }\end{array}$ & 2.20 & 1.00 \\
\hline & Total & $\mathbf{2 . 3 5}$ & $\mathbf{0 . 8 3}$ \\
\hline
\end{tabular}

The finding showed the highest mean value for modern poetry comprehension aspect is (mean=2.93; $\mathrm{SD}=1.07$ ) related to "Can you explain the consequences of taking drug on an individual?". The second highest $($ mean $=2.20 ; S D=1.00$ ) related to "What is the best solution for combating drug abuse??". While the lowest (mean=1.92; SP $=1.01$ ) related to "Why are those who involved in drug addiction are wasting human resource of the country?". The summary, overall mean value and the standard deviation for the aspect of HOTS level in understanding modern poetry is (mean $=2.35 ; \mathrm{SD}=0.83$ ). This finding as a whole shows the HOTS level of Form 3 pupils in understanding of modern poetry is at a moderate level.

Meanwhile, regarding the HOTS level of form 3 students in aspect of modern prose comprehension, it showed that the aspect of HOTS level of form 3 students; 100 (47.6\%) have high HOTS, 63 (30\%) have medium, and 47 (22.4\%) have low HOTS. Refer to table 7 below. 
INTERNATIONAL JOURNAL OF ACADEMIC RESEARCH IN BUSINESS AND SOCIAL SCIENCES Vol. 8, No. 12, Dec, 2018, E-ISSN: 2222-6990 @ 2018 HRMARS

Table 7: HOTS Level of Form 3 Students in Understanding Modern Prose

\begin{tabular}{|l|l|l|l|l|}
\hline HOTS (Modern Prose) & Frequency (f) & $\begin{array}{l}\text { Percentage } \\
(\%)\end{array}$ & Mean & SD \\
\hline Low & 47 & 22.4 & & \\
\hline Medium & 63 & 30 & & \\
\hline High & 100 & 47.6 & & \\
\hline Total & 210 & 100.0 & 2.67 & 0.98 \\
\hline
\end{tabular}

Overall, the HOTS level of form three students on the aspect of modern prose understanding is at high level with (mean $=2.67 ; \mathrm{SP}=0.98$ ) as shown in Table 8 below:

Table 8: HOTS Level in Understanding Modern Prose

\begin{tabular}{|l|l|l|l|}
\hline Item & Statement & Mean & SD \\
\hline 1 & $\begin{array}{l}\text { Based on the above passage, what is your assumption on a } \\
\text { mother who is being strict on her kid since small? }\end{array}$ & 2.64 & 1.10 \\
\hline 2 & $\begin{array}{l}\text { In your opinion, why the education is important for a } \\
\text { teenager as emphasized by the author? }\end{array}$ & 2.94 & 1.06 \\
\hline 3 & $\begin{array}{l}\text { After reading this short story, what do you do to change the } \\
\text { kid's attitude if you are one of kid's family member? }\end{array}$ & 2.42 & 1.16 \\
\hline Total & & $\mathbf{2 . 6 7}$ & $\mathbf{0 . 9 8}$ \\
\hline
\end{tabular}

The finding showed that the highest mean value of HOTS in aspect of understanding modern prose was mean $=2.94$, $(S D=1.06)$ which was related to "Why the education is important for a teenager as emphasized by the author?" The second highest mean=2.64, $(S D=1.10)$ which was related to "Based on the above passage, what is your assumption on a mother who is being strict on her kid since small?". While the lowest mean= 2.42 (SD = 1.16) which was related to "After reading this short story, what do you do to change the kid's attitude if you are one of kid's family?" In a nutshell, the overall mean value and the standard deviation of HOTS level in aspect of modern prose comprehension was mean $=2.67,(S D=0.98)$. This finding as a whole showed the HOTS level of form three students on the understanding of modern prose is at high level.

Identifying is there a significant difference in HOTS between female and male students in the understanding of modern poetry and prose 
INTERNATIONAL JOURNAL OF ACADEMIC RESEARCH IN BUSINESS AND SOCIAL SCIENCES Vol. 8, No. 12, Dec, 2018, E-ISSN: 2222-6990 @ 2018 HRMARS

Based on the differences of HOTs between male and female students in the understanding of modern poetry, the finding based on independent t-test indicated that there was no significant difference in the HOTS score between male and female students $(210)=-1.478, p=0.141>0.05$. This was explained that there was no significant difference in the HOTS level of understanding modern poetry between male students (mean=2.26; SD =0.83) and female students (mean=2.43; SD =0.83). The findings also showed that HOTS levels between male and female students were same and there was no difference. Refer to Table 9 below.

Table 9: Different Level of HOTS in the Understanding of Modern Poetry according to Gender

\begin{tabular}{|c|c|c|c|c|c|c|}
\hline Modern Poetry & $\mathbf{N}$ & Mean & SD & $\mathbf{T}$ & $d f$ & $P$ \\
\hline \multicolumn{7}{|l|}{ Gender } \\
\hline Male & 94 & 2.26 & 0.83 & -1.478 & 198.73 & 0.141 \\
\hline Female & 116 & 2.43 & 0.83 & & & \\
\hline
\end{tabular}

*significant $p<.05$

Meanwhile, the differences of HOTS between male and female students in modern prose comprehension based on independent t-tests showed that there was a significant difference in the HOTS mean in the understanding of modern prose between male and male ( mean = 2.47; SD = 1.03) The result shows that female students have higher HOTS level than male students. However, when be examined, the mean for female was only slightly different $(p<0.03)$ than male students although there was a significant difference. Refer to Table 10 below.

Table 10: Different level of HOTS in the Understanding of Modern Prose according to Gender

\begin{tabular}{|l|l|l|l|l|l|l|l|}
\hline Modern Prose & N & Mean & SD & t & \multicolumn{1}{l|}{$\boldsymbol{d f}$} & $\boldsymbol{P}$ \\
\hline Gender & \multicolumn{9}{|l|}{} & \\
\hline Male & 94 & 2.47 & 1.03 & -2.698 & 187.71 & 0.008 \\
\hline Female & 116 & 2.83 & 0.91 & & & \\
\hline
\end{tabular}

*significant $p<.05$

The difference of HOTS achievement level in aspects of understanding modern poetry and prose between high, medium and low level students

The finding was to identify the differences of HOTS achievement levels in aspect of understanding modern poetry and prose between high, medium and low level students. The dependent variable was the level of achievement of students; high, medium and low. Meanwhile, the independent variable or factor was the degree of HOTS's achievement in aspect of modern poetry comprehension. A one-way Anova test was used to determine whether there is a significant difference in the level of achievement in understanding modern poems among all three group levels of students. The one-way ANOVA test was used to determine the differences in the level of HOTS achievement in aspect of understanding modern poetry based on students' achievement. Table 11 below shows the one-way 
INTERNATIONAL JOURNAL OF ACADEMIC RESEARCH IN BUSINESS AND SOCIAL SCIENCES Vol. 8, No. 12, Dec, 2018, E-ISSN: 2222-6990 @ 2018 HRMARS

ANOVA results for Student Achievement Distribution based on the degree of HOTS achievement in aspect of understanding modern poetry.

Table 11: HOTS Differences in Modern Poetry Comprehension Based on Students' Group of High, Medium and Low level

\begin{tabular}{llllll}
\hline $\begin{array}{l}\text { HOTS Achievement Level } \\
\text { in Modern Poetry }\end{array}$ & Sum of Square & Df & Mean square & $\boldsymbol{F}$ & $\begin{array}{l}\text { Sig } \\
(\boldsymbol{p})\end{array}$ \\
\hline Between Group & 61.558 & 2 & 30.779 & 77.124 & .000 \\
Within Group & 82.611 & 207 & .399 & & \\
\hline Total & $\mathbf{1 4 4 . 1 6 9}$ & $\mathbf{2 0 9}$ & & & \\
\hline
\end{tabular}

Table 11 shows the differences of HOTS level in the understanding of modern poetry based on group level of students. Based on table 12, there was a significant difference in the mean score of the achievement of HOTS in aspect of understanding modern poetry based on the high, medium and low group of students $F(2,207)=77.124,<0.05)$. The mean score achievement was significantly different at less than 0.05

The difference in the level of the achievement of HOTS in aspect of understanding modern prose based on student-group performance.

One-way ANOVA was used to determine the difference in the level of achievement of HOTS in aspect of understanding modern prose based on group level of students i.e high, medium and low. This analysis was carried out to identify to what extent HOTS achievement in the understanding of modern prose depends on the student-level. In other words, the level of HOTS achievement in modern prose differs according to the high, medium and low level of students.

Table 12: HOTS Difference in Modern Prose Understanding Based on Student Performance Groups

\begin{tabular}{llllll}
\hline $\begin{array}{l}\text { HOTS Achievement } \\
\text { Level in Modern Prose }\end{array}$ & Sum of Square & $\boldsymbol{d f}$ & Mean square & $\boldsymbol{F}$ & $\begin{array}{l}\text { Sig } \\
(\boldsymbol{p})\end{array}$ \\
\hline Between Group & 53.699 & 2 & 26.850 & 37.990 & .000 \\
Within Group & 146.299 & 207 & .707 & & \\
\hline Total & $\mathbf{1 9 9 . 9 9 8}$ & $\mathbf{2 0 9}$ & & & \\
\hline
\end{tabular}

Table 12 above shows the differences of HOTS in understanding modern prose based on group of students. Based on the table, there was a significant difference in the mean score of the achievement of HOTS in aspect of modern prose comprehension based on high, medium and low-group students $(2,207)=37.990,<0.05)$. The mean score is significantly different at levels less than 0.05 . 
INTERNATIONAL JOURNAL OF ACADEMIC RESEARCH IN BUSINESS AND SOCIAL SCIENCES

Vol. 8, No. 12, Dec, 2018, E-ISSN: 2222-6990 @ 2018 HRMARS

\section{Discussion, Suggestion and Conclusion Discussion}

Overall, the HOTS level of form three students in aspect of modern poetry comprehension was at a moderate level with mean value and standard deviation $2.35,(S D=0.83)$. This is because of the understanding of poetry actually requires students to understand and analyze what the poets try to convey. The most difficult thing for them to answer this question was because of poet's language factor and comprehensive question factors that confused them. According to Zailan Shuib (2010), this level is more than a concept that requires students to interpret something that is implied by deep thinking.

In the meantime, HOTS level of form three students on aspect of understanding modern prose is at high level (47.6\%). 63 students (30\%) had moderate HOTS level, and 47 (22.4\%) had low HOTS level. The overall mean value and the standard deviation of HOTS level on aspect of understanding modern prose is mean $=2.67,(S D=0.98)$. The finding of students' understanding modern prose shows that it is easier for students to answer questions based on a stimuli provided. Compared to the understanding poetry that is limited space of choice of answers for students to explain the ideas more relevance. Prose comprehensiveness is easier to find the suitable answers in answering the questions. The text provided with answers is only for the student to vigorously find out the accurate and relevant idea to particular questions. As such, understanding the modern prose for students to attain HOTS level is higher than understanding the poetry. The study conducted by Yahya Othman and Dayang Raini Pakar (2011), aimed to evaluate student achievement in comprehension and reading. This study found that there was no significant difference in mean of reading comprehension performance between experimental group and control group in pre-test. Similarly, the findings of this study showed that students who answered modern prose questions could still answer well regardless of answering the questions for the first time.

This means that students from different levels of achievement either high, medium or low have the ability to answer comprehensive question better than poetry comprehensive question. This is because of the stimulus-source makes them easier to find the answers for each given question.

Meanwhile, the finding on gender show that female's HOTS is higher than male. This is because of the natural factors of female students who are said to be more motivated to learn especially in the form of reading and understanding. The high level of effort, creativity and dedication of female students can improve their achievement in learning process. So, it is not strange if their level of HOTS is higher than boys in answering modern prose comprehensive question. This is supported by the study of Nur Aisyah Mohamad, Zamri Mahamod \& Sharala a/p Subramaniam (2013), which found that female students got better metacognitive level than male students in Malay language due to their different learning styles. Furthermore, in a study carried out by Ong, Sze Chong, Zamri Mahamod \& Hamidah Yamat (2013), found that better learning process is also because of conducive learning environment such as inclusive school infrastructure that can facilitate their learning process. 


\section{Suggestion}

The researcher found that the students' high-order thinking skill can be improved. Students' level of achievement in term of thinking skills, especially in aspects of comprehension needs to be refine according to the 21st century learning which requires a high level of thinking. The researcher found that the teachers and the Malay Language Committee especially in this school need to make a change in teaching and learning process as result of moderate HOTS among students as a whole.

In addition, teaching and learning should be based on 21st century learning by using various appropriate teaching aids and applying the I-Think thinking map especially in the aspect of understanding KOMSAS. The high level of questioning as well as brainstorming ideas between teachers and students can generate high-order thinking skills among students. The Malay language teachers need to emphasize how to answer HOTS questions. This is because the students need to be taught to comprehend better before answering the question. Exercises to answer a variety of questions are also very important to them. It will enhance their understanding of particular subject in one lesson as well as to improve their high-order thinking skills. Besides that, Malay Language teachers need to give positive guidance in generating students' thinking skills. In addition to aspects of questioning and developing the questions, teachers' instruction aspects play an important role and have long-term impact on the students.

\section{Conclusion}

The High-order Thinking Skills (HOTS) is an important element that students should grasp in solving the comprehensive question of Malay Language. If lower level question gives them a problem especially among low level achievers, therefore, it is likely same for the high level. Therefore, this study gives an early understanding of HOTS as well as to improve the teaching of teachers in the classroom. Teachers need to use various suitable teaching methods according to students' level so that they can accept and apply HOTS in order to answer Malay poetry and prose comprehensive questions.

Eventually, teachers and pupils need to be highly conscious on HOTS aspect. It is necessary for all Malay language teachers to cooperate continuously in improving student achievement of HOTS in understanding poetry and prose of Malay literary components. Developing a module to answer HOTS questions in terms of understanding brings a lot of benefits to the students. Meanwhile, a standard module-based for all teachers will possibly increase student achievement in Malay language. Thus, this learning activity is suitable for all levels of students' performance instead of focusing only on problematic students. Medium and high achievers are also needed as a reinforcement and enrichment activity to answer Malay Language comprehensive question.

In addition, to develop the mind of students in HOTS, the role of a teacher is very important. Teachers need to play an important role in ensuring that pupils have high HOTS skills such as conducting questionnaire session with students in the classroom. Practice questioning and using high-level questioning can also stimulate their thinking to think in solving the issues and issues raised. This activity is not only to improve the efficiency of the students but also to make the teaching and 
INTERNATIONAL JOURNAL OF ACADEMIC RESEARCH IN BUSINESS AND SOCIAL SCIENCES

Vol. 8, No. 12, Dec, 2018, E-ISSN: 2222-6990 C 2018 HRMARS

learning process more fun and effective. In conclusion, it is hoped that this study will give students an awareness of the importance of high-order thinking skills as a preparation not only in answering the exam questions but also to enter the working world and go through daily life.

\section{References}

Abu Bakar N. (2013). "Kurikulum Kearah Penghasilan Kemahiran Berfikiran Kritis, Kreatif dan Inovatif Fakulti Pendidikan, Universiti Malaya". Juku: Jurnal Kurikulum \& Pengajaran Asia Pasifik - Bil. 1 Isu 1.

Anderson, L. W. \& David R. Krathwohl, D. R., et al (Eds.). (2001). A Taxonomy for Learning, Teaching and Assessing: A Revision of Bloom's Taxonomy of Educational Objectives. Allyn \& Bacon. Boston: MA Pearson Education Group.

Azizi Y., Asmah S., Zurihanmi Z., \& Fawziah Y. (2005). Aplikasi Kognitif dalam Pendidikan. Bentong, Pahang: PTS Professional Publishing Sdn.Bhd.

Bloom, B.S., Englehart, M., Furst, E., Hill, W. \& Krathwohl, D.R. (1956). Taxonomy of Educational Objectives: Cognitive Domain. New York: Longman.

Chew F. P. (2014). "Pelaksanaan Kemahiran Berfikir Kreatif dan Kritis dalam Pengajaran dan Pembelajaran Komsas di Sekolah Menengah". Jurnal Pendidikan Bahasa Melayu. Vol. 4, Bil. 2 (Nov. 2014), 10-24.

Edward B. (2000). "Serious Creativity 2: The Heed for Creative Thinking and The Application of Creative Thinking." 1st Edition. England: Penguin Group.

Jamal @ Nordin Y., Khuan W. B., Marinah A., Suzyanty M. S. \& Zuraidah Z. (2011). Pemikiran Kritis dan Kreatif. Petaling Jaya, Selangor: Pearson Malaysia Sdn. Bhd.

Kementerian Pelajaran Malaysia, (2012). Pelan Pembangunan Pendidikan Malaysia 2013-2025. Kuala Lumpur.

Kementerian Pelajaran Malaysia, (2013). Program Kemahiran Berfikir Aras Tinggi. Kuala Lumpur.

Lembaga Peperiksaan. (2013). Pentaksiran Kemahiran Berfikir Aras Tinggi. Kementerian Pendidikan Malaysia, Kuala Lumpur.

Noraini I. \& Shukri O. (2009). Pengajaran dan Pembelajaran (Teori dan Praktis). Kuala Lumpur: Mc Graw Hill (M) Sdn Bhd.

Noraini I. (2010). Penyelidikan dalam Pendidikan. Petaling Jaya: Mcgraw-Hill (M) Sdn. Bhd. 
INTERNATIONAL JOURNAL OF ACADEMIC RESEARCH IN BUSINESS AND SOCIAL SCIENCES

Vol. 8, No. 12, Dec, 2018, E-ISSN: 2222-6990 C 2018 HRMARS

Nur Aisyah M., Zamri M., \& Sharala S. (2013). “Kemahiran Meta Kognitif dan Hubungannya dengan Jantina, Jenis Sekolah dan Pencapaian Murid dalam Pembelajaran Bahasa Melayu". Jurnal Pendidikan Malaysia 38(2) (2013): 23-32.

Som N. \& Mohd D. (2000). Kemahiran berfikir. Kuala Lumpur: Longman Malaysia Sdn. Bhd.

Suppiah N., Ramlah J., \& Abdul Aziz A. S. (2008). Siri Pendidikan Guru: Psikologi Pendidikan. Shah Alam, Selangor: Oxford Fajar Sdn. Bhd.

Yahya O. (2007). Mengajar Membaca: Teori \& Aplikasi Panduan Meningkatkan Kemahiran Mengajar Membaca Edisi Kedua. Kuala Lumpur: PTS Professional Publishing Sdn. Bhd. 